\title{
Klinik Hemşirelerinin Sağlıklı Çalışma Ortamı Standartlarına Göre Çalışma Ortamlarını Değerlendirmeleri
}

\author{
Duru YAPICI ${ }^{1}$, (iD Havva ARSLAN YÜRÜMEZOĞLU²
}

${ }^{1}$ Uzman Hemşire, Abdulkadir Yüksel Devlet Hastanesi, Süt Çocuğu Kliniği, Gaziantep, Türkiye.

${ }^{2}$ Doç. Dr., Dokuz Eylül Üniversitesi, Hemşirelik Fakültesi, Hemşirelikte Yönetim Anabilim Dalı, İzmir, Türkiye.

$\ddot{O ̈ z}$

Giriş: Kaliteli sağlık bakımı ve olumlu hasta sonuçlarının büyük oranda iyi bir hemşirelik bakımının sonucu olması hemşirelerin çalışma ortamlarının iyileştirilmesinin önemini göstermektedir. Amaç: Türkiye'de hemşireler için geliştirilmiş sağlıklı çalışma ortamı standartlarının kamu hastanelerinde uygulanma durumunu ve bu standartların hemşireler için önemlilik ve öncelik düzeyini belirlemek amacıyla yapılmıştır. Yöntem: Araştırmanın örneklemini İzmir ilinde Sağlık Bakanlığı'na bağlı üç eğitim araştırma hastanesinin cerrahi, dahili ve yoğun bakım birimlerinde doğrudan hasta bakımı sunan 550 klinik hemşire oluşturmaktadır. Örnekleme araştırmaya gönüllü olarak katılmayı kabul eden ve kurumda en az bir yıl çalışmış olan 309 hemşire alınmıştır. Veri toplama aracı olarak Bireysel ve Çalışma Özellikleri Formu ve araştırmacılar tarafından sağlıklı çalışma ortamı standartları dikkate alınarak hazırlanan üç form kullanılmıştır. Veriler SPSS 22.0 istatistik programı kullanılarak tanımlayıcı istatistikler, non-parametrik tek yönlü varyans analizi ve Bonferroni Düzeltmeli Mann-Whitney U testi ile değerlendirilmiştir. Araştırmanın yürütüldüğü hastanelerin yönetimlerinden yazılı izin ve üniversitenin etik kurulundan onay alınmıştır. Bulgular: Standartların tümünün uygulanma durumu 2.07 (0.49), Etkili Yönetim ve Liderlik” ana standard1 1.76 (0.60) ile en düşük, "Ekip İş Birliği, İletişim, Takdir ve Tanınma" ana standardı ise 2.27 (0.63) ile en yüksek ortalamaya sahiptir. Hemşirelerin \%80.3'ü "Hemşire İş Yükü" ana standardını en önemli, \%70.3'ü de en öncelikli olarak bildirmişlerdir. "Uygun Fiziki Koşullar ve Yeterli Araç-Gereç" ana standardının yoğun bakım birimlerinde daha düşük düzeyde uygulandığı ifade edilmiştir. Sonuç: Bu çalışmanın sonuçları, klinik hemşirelerinin çalıştıkları kurumlarda sağlıklı çalışma ortamı standartlarının düşük-orta düzeyde uygulandığını düşündüklerini göstermiştir.

Anahtar kelimeler: Hemşireler, Sağlıklı Çalışma Ortamı, Standartlar.

\section{Abstract}

\section{Evaluation of Working Environment by Clinical Nurses According to Healthy Working Environment}

\section{Standards}

Background: The fact that quality health care and positive patient outcomes depend largely on good nursing care reveals the importance of improving the working environment of nurses. Objective: This study was conducted to investigate the extent to which the healthy working environment standards developed for nurses in Turkey were implemented in healthcare institutions and the perception of nurses concerning the importance and priority of main standards in creating a healthy working environment. Methods: The sample of the study consisted of 550 clinical nurses providing direct patient care in the surgical, internal medicine and intensive care units of three education research hospitals affiliated with the Ministry of Health in Izmir. A total of 309 nurses, who accepted to participate in the study and had worked in their current institution for at least one year, were included in the sample. The Individual and Work Characteristics Form and three forms prepared by the researchers taking into account the healthy work environment standards were used as data collection tools. Data were evaluated by descriptive statistics, non-parametric one-way analysis of variance, and the Mann-Whitney U test with the Bonferroni correction using SPSS v. 22.0. Written permission was obtained from the hospitals where the research was to be conducted, and the ethics committee of the university approved the study. Results: While the implementation of all of the standards had an average of 2.07 (0.49), the main standard of "Effective Management and Leadership" had the lowest average at 1.76 (0.60) and "Team Collaboration, Communication, Appreciation and Recognition" had an average of 2.27 (0.63). "Nurse Workload" was considered to be the most important Standard by 80.3\% of the nurses and most prioritized by $70.3 \%$. It was staed that the main standard of "Suitable Physical Conditions and Adequate Tools-Equipment" was implemented at a lower level in intensive care units. Conclusion: The results of this study showed that the clinical nurses considered that all the standards of healthy working environment were implemented at a low to moderate level in their institutions.

Key Words: Nurses, Healthy Working Environment, Standards.

Geliş Tarihi / Received: 13.10.2020 Kabul Tarihi / Accepted: 08.07.2021

Correspondence Author: Uzman Hemşire, Abdulkadir Yüksel Devlet Hastanesi, Süt Çocuğu Kliniği, Gaziantep, Türkiye. Telefon: +90(532)2566052 Eposta: duruypc@outlook.com (ORCID:0000-0003-3601-4562)

Cite This Article: Yapıcı D, Arslan Yürümezoğlu H. Klinik Hemşirelerinin Sağlıklı Çalışma Ortamı Standartlarına Göre Çalışma Ortamlarını Değerlendirmeleri. Dokuz Eylül Üniversitesi Hemşirelik Fakültesi Elektronik Dergisi. 2021; 14(3): 240- 252 
$\mathbf{H}$ emşirelik çalışma ortamı, etkin ve verimli sağlık hizmeti verilebilmesi açısından oldukça önemli bir konu olmasına rağmen hemşirelere temel standartlara sahip, sağlıklı ve destekleyici çalışma ortamı sağlanamadığı bilinmektedir. Bunun yanı sıra, hemşirelerin çalışma ortamları kurumlara ve hatta birimlere göre değişiklik göstermektedir. Yapılan çalışmalarda, hemşireler tarafından yoğun bakım birimlerindeki çalışma ortamlarının, cerrahi ve dahili birimlere göre daha kötü algılandığı belirlenmiştir (1). Çalışma ortamlarını ve iş yaşamı kalitelerini orta ya da kötü olarak değerlendiren hemşirelerin kurumdan ayrılma niyeti yüksek ve işlerinden memnuniyet düzeyleri düşük bulunmuştur (2-4). Hemşirelerin kurumdan ayrılma nedenleri incelendiğinde kariyer gelişiminin olmaması, ücret azlığı, yapılan işe göre ek ödemenin azlığı, hasta/hemşire oranlarının yüksek olması ve nöbet sayılarının fazlalığı gibi çalışma ortamının özelliklerine ilişkin faktörler olduğu gösterilmiştir $(5,6)$. Motive edici ve destekleyici olumlu bir çalışma ortamının hemşirelerin memnuniyetini, iş doyumunu ve kariyer başarısını artırdığı, hemşireleri kurumda tutmayı sağladığı ve devir hızını düşürdüğü pek çok çalışma sonucuyla gösterilmiştir (7-10). Bunların yanı sıra olumlu çalışma ortamının yeni mezun hemşirelerin yetkinliğini, memnuniyetini arttırdığı ve kurumda kalmasını sağladığı da vurgulanmaktadır (11). Bu durum uzun vadede bakım kalitesinin artması ve bakımın sürekliliğinin sağlanması gibi hasta sonuçlarını olumlu etkilemesi açısından da oldukça önemlidir. Çünkü çalışma ortamının koşulları sadece hemşireleri değil, hemşirelerin hizmet verdiği bireyleri de etkilemektedir. Hemşirelere sağlıklı çalışma ortamı sağlandığında hasta düşmeleri, bası yarası ve mortalite oranlarının azaldığı, hastaların ağrı yönetiminin daha iyi yapıldığı, bakım kalitesinin ve hasta memnuniyetinin arttığı gösterilmiştir (12-15). Hemşire ve hasta sonuçları üzerine olumlu etkisi göz önüne alındığında hemşirelere sağlıklı çalışma ortamının oluşturulmasının önemi açıktır.

Hemşireler için sağlıklı çalışma ortamı tanımları ve çalışmaları hemşirelikte öncü kuruluşlar tarafından yapılmıştır. Uluslararası Hemşirelik Konseyi (International Counsil of Nurses/ICN) sağlıklı çalışma ortamını, hemşirelerin kurumda tutulmasına odaklanmış, yenilikçi politikaları, sürekli gelişimi ve eğitim stratejilerini önemseyen, çalışanların yeterli ücret alabildiği, ekipman ve malzemeleri gereken düzeyde bulunduran, güvenli bir çalışma sağlayan uygulama ortamları olarak nitelendirmektedir (16). Ontario Kayıtlı Hemşireler Derneği (Registered Nurses Association of Ontorio/RNAO) ise sağliklı çalışma ortamı hemşirenin sağlığını ve refahını yükselten, kaliteli hasta sonuçlarına ulaştıran, örgütsel performansı ve sosyal sonuçları en iyi seviyeye getiren uygulama ortamları olarak tanımlamıştır. Yine aynı kuruluş 2003 yılında hemşireler için sağlıklı çalışma ortamları oluşturulması amacıyla ilk adımları atarak, kanıta dayalı en iyi uygulama kılavuzlarını geliştirmiştir (17). Amerikan Yoğun Bakım Hemşireleri Birliği (American Association of Critical-Care Nurses/AACN), 2005 yılında dokuz kişilik bir uzman paneli oluşturarak hemşirelere sağlıklı çalışma ortamlarının oluşturulması ve sürdürülmesi için "Nitelikli İletişim, İş̧ Birliği, Etkili Karar Verme, Yeterli Personel, Tanıma ve Liderlik" şeklinde altı standart belirlemiştir (18). Standartlar belirlendikten sonra ABD'deki mevcut durumu değerlendirmek için ulusal hemşirelik araştırmaları yapılmıştır. Yapılan ilk araştırmada, nitelikli iletişim, iş birliği ve yeterli personel standartlarının diğer standartlardan daha düşük düzeyde sağlandığı belirlenmiştir (19). Daha sonra 2009 yılında tekrarlanan izlem araştırmasında, genel olarak tüm standartların puanlarının biraz arttığı saptanmıştır (20). Ancak 2014'te tekrarlanan araştırmada, puanı artan tek standardın iletişim olduğu, diğer standartların puanlarının önceki yılların altında kaldığı görülmüştür (21). Son olarak 2019 yılında yapılan araştırmada ise tüm standartların 2014 yılındaki puanlardan daha yüksek puan aldığı belirlenmiş, sağlıklı çalışma ortamının stabil bir koşul olmadığını; sürekli izlenerek iyileştirilmeler yapılması gerektiğine dikkat çekilmiştir (22).

Ülkemizde hemşirelerin çalışma ortamlarına dair yapılan araştırmalar incelendiğinde, daha çok hemşirelerin çalışma ortamlarını nasıl algıladıkları ile ilgilenildiği görülmektedir. Bu çalışmaların sonuçları, hemşirelerin çalışma ortamlarını orta düzeyde algıladıklarını göstermektedir $(1,3,23,24)$. Samur ve İntepeler'in (2019) yaptıkları nitel bir araştırmada ise hemşirelerin çalışma ortamlarını sağlıklı ve güvenli bulmadıkları belirlenmiş, fiziksel ortama ilişkin düzenlemeler ve yönetici tutumları ana temaları altında tamamıyla çalışma ortamını yansıtan alt temalar yer almıştır (25). Kocaman ve arkadaşlarının (2018) "Türkiye'de Hemşireler İçin Sağlıklı Çalışma Ortamı Standartlarının Geliştirilmesi” projesi ise hemşirelerin çalışma ortamlarının iyileştirilmesine yönelik atılan ilk ve önemli adımdır. Özel, üniversite ve devlet hastanelerinde çalışan yöneticiler, hemşireler ve hemşirelikte yönetim alanında uzman akademisyenlerin e-Delphi yöntemi ile konuya ilişkin görüşleri alınmış, bu çalışmanın sonucunda ülkemize özgü hemşireler için sağlıklı çalışma ortamı standartları geliştirilmiştir. Hemşire İş Yükü, Gelişstirme ve Kariyer Planlama, Sosyal Haklar, İ̧s Sağllğı ve Güvenliği, Uygun Fiziki Koşullar ve Yeterli Araç-Gereç, Ekip İş Birliği, İletişim, Takdir ve Tanınma ve Etkili Yönetim ve Liderlik olmak üzere altı ana standart ve bu ana standartlara bağlı 35 alt standart belirlenmiştir (26).

\section{Amaç}

Türkiye'de Hemşireler İçin Sağlıklı Çalışma Ortamı Standartlarının Geliştirilmesi Projesi'nde belirlenen standartların hayata geçirilmesine yol göstermesi açısından, doğrudan hasta bakımı veren hemşirelerden oluşan bir örneklem ile değerlendirilmesine gereksinim duyulmuştur. Bu gereksinimden yola çıkılarak planlanan araştırma, Sağlık Bakanlığı'na bağlı eğitim araştırma hastanelerinde erişkin cerrahi, dahili ve yoğun bakım birimlerinde sağlıklı çalışma ortamı (SÇO) standartlarının uygulanma durumunun her standart için ayrı değerlendirilmesi, birimler arasında standartların uygulanma durumu açısından farklılık olup olmadığı, sağlıklı çalışma ortamı oluşturulmasında ana standartların hemşireler için önemlilik ve öncelik düzeyinin belirlenmesi amacıyla yapılmıştır.

\section{Araştırma Sorulart}

- Sağlıklı çalışma ortamı standartlarının kurumda uygulanma durumunu klinik hemşireleri ne düzeyde değerlendiriyor?

- Sağlıklı çalışma ortamı ana standartlarının klinik hemşireleri için önemlilik düzeyi nedir?

- Sağlıklı çalışma ortamı ana standartlarının klinik hemşireleri için öncelik sıralaması nasıldır?

- Sağlıklı çalışma ortamı standartlarının cerrahi, dahili ve yoğun bakım birimlerinde uygulanma durumu arasında fark var midır? 


\section{Araştırmanın Tipi}

\section{Yöntem}

Bu çalışma tanımlayıcı ve kesitsel tipte yapılmıştır.

Araştırmanın Yeri ve Zamanı

Araştırma İzmir İlindeki Sağlık Bakanlığı'na bağlı üç kamu eğitim ve araştırma hastanesinde Eylül-Ekim 2019 tarihleri arasında yapılmıştır. Hastanelerin yatak kapasitesi sırasıyla 688, 992, 650'dir. Çalışan hemşire sayıları ise sırasıyla 469, 492, 269'dur.

\section{Araştırmanın Örneklemi}

Araştırmanın örneklemini üç kamu hastanesinde erişkin cerrahi, dahili ve yoğun bakım birimlerinde doğrudan hasta bakımı sunan, araştırmaya gönüllü olarak katılmayı kabul eden ve kurumda en az bir yıl çalışmış olan 550 klinik hemşire oluşturmaktadır. Kurumda en az bir yıl çalışmış olması kriteri, çalışma ortamını yeteri kadar değerlendirebilecek hemşirelerden verilerin toplanmasının daha doğru sonuçlara ulaştıracağı nedeniyle belirlenmiştir. Hastanelerden sırasıyla hemşirelerin anketlere geri dönüş oranı \%56.11, \%53.62 ve \%61.47'dir. Araştırmada toplam 309 anketten elde edilen veriler analizlere dahil edilmiştir. G Power yazılım programında post hoc güç analizi için 0.50 etki büyüklüğü, $\% 5$ hata payı 309 örneklem ile varyans analizi için güç 0.99 bulunmuştur. Çalışmanın örneklemini oluşturan hemşirelerin özellikleri Tablo 1'de verilmiştir.

Tablo 1. Hemşirelerin Bireysel ve Çalışma Özellikleri

\begin{tabular}{|c|c|c|c|}
\hline Özellikler & & Ort & \\
\hline $\begin{array}{l}\text { Yaş } \\
\text { Yer işareti tanımlanmamış. } \\
\text { Meslekte Çalışma Süresi } \\
\text { Kurumda Çalışma Süresi }\end{array}$ & $\begin{array}{l}(n=293 *) \\
(n=308 *) \\
(n=309 *)\end{array}$ & $\begin{aligned} & \text { Hata! } 33.89 \\
& 12.49 \\
& 6.94\end{aligned}$ & \\
\hline Cinsiyet & & Sayı & $\%$ \\
\hline $\begin{array}{l}\text { Kadın } \\
\text { Erkek }\end{array}$ & & $\begin{array}{l}280 \\
29\end{array}$ & $\begin{array}{l}90.6 \\
9.4\end{array}$ \\
\hline
\end{tabular}

\begin{tabular}{lll}
\hline Eğitim Durumu & Sayı & $\%$ \\
\hline
\end{tabular}

$\begin{array}{lll}\text { Lise } & 14 & 4.5 \\ \text { Ön Lisans } & 59 & 19.1 \\ \text { Lisans } & 206 & 66.7 \\ \text { Lisansüstü } & 30 & 9.7\end{array}$

\begin{tabular}{lll}
\hline Birimler & Sayı & $\mathbf{\%}$ \\
\hline & & \\
Cerrahi Birimler & 100 & 32.4 \\
Dahili Birimler & 116 & 37.5 \\
Yoğun Bakım Birimleri & 93 & 30.1 \\
\hline TOPLAM & & \\
\hline
\end{tabular}

*Çalışmaya katılan hemşirelerin bazı sorulara yanıt vermemesi nedeniyle yalnızca yanıt verenlerin ortalamalarını içermektedir.

\section{Veri Toplama Araçları}

Çalışmada veriler Bireysel ve Çalışma Özellikleri, SÇO standartlarına dayalı olarak hazırlanan SÇO Standartlarının Kurumda Uygulanma Durumunun Değerlendirilmesi, SÇO Ana Standartlarının Önemlilik Derecesini Değerlendirilmesi ve SÇO Ana Standartlarının Öncelik Sıralamasının Değerlendirilmesi formları ile toplanmıştır.

- Bireysel ve Çalışma Özellikleri Formu: Bu formda bireysel ve çalışma özelliklerine ilişkin yaş, cinsiyet, eğitim derecesi, çalıştığı hastane türü, kurumda çalışma yılı, meslekte çalışma yılı ve çalıştığı kliniğe ilişkin sorular yer almaktadır.

- SÇO Standartlarının Kurumda Uygulanma Durumunun Değerlendirilmesi: Kocaman ve ark. (2018) tarafindan geliştirilmiş olan 35 maddelik Türkiye'de Hemşireler İçin Sağlıklı Çalışma Ortamı Standartları'nı içermektedir (26). Formun puanlanmasında AACN'nin standartlarının değerlendirildiği form örnek alınarak 4'lü Likert tipinde hazırlanmıştır (hiç katılmıyorum: 1, katılmıyorum: 2, katılıyorum: 3, tamamen katılıyorum: 4) (20). Veriler madde bazında yüzde, ortalama ve standart sapma hesaplanarak değerlendirilmiştir.

- SÇO Ana Standartlarının Önemlilik Derecesinin Değerlendirilmesi: Bu bölüm altı ana standardın (Hemşire İş Yükü, Geliştirme ve Kariyer Planlama, Sosyal Haklar, İş Sağlığı ve Güvenliği, Uygun Fiziki Koşullar ve Yeterli Araç-Gereç, Ekip İş Birliği, İletişim, Takdir ve Tanınma, Etkili Yönetim ve Liderlik) hemşireler tarafından önemlilik derecesinin belirlenmesi için Likert'in 7'li önem düzeyi ölçeği (çok önemsiz: 1, oldukça önemsiz: 2, önemsiz: 3, fikrim yok: 4, önemli: 5, oldukça önemli: 6, çok önemli: 7) kullanılarak hazırlanmıştır (27). Madde puanları yüzde, ortalama ve standart sapma hesaplanarak değerlendirilmiştir.

- SÇO Ana Standartlarının Öncelik Sıralamasının Değerlendirilmesi: Bu bölümde hemşirelerden altı ana standardı çalıştıkları kurumlarda uygulamaya geçirilmesi için öncelik sıralaması yapmaları istenmiştir. Bunun için altılı bir derecelendirme 
kullanılmıştır (1: çok öncelikli 6: az öncelikli olacak şekilde). 1'den 6'ya doğru sıralama yapmaları istenmiştir. Maddeler sadece yüzde hesaplanarak değerlendirilmiştir.

\section{Verilerin Toplanmast}

Veri toplama sürecinde Eylül-Ekim 2019 tarihlerinde araştırmacı tarafindan öncelikle birimlerin sorumlu hemşireleri ve hemşirelerle yüz yüze görüşülerek araştırma hakkında bilgi verilmiştir. Araştırmaya katılımın gönüllülük esasına dayandığı belirtilmiş, verilerin gizliliği konusunda güvence verilmiştir. Veri toplama formları kapalı zarf içerisinde araştırmacı tarafindan teslim edilmiştir. Hemşireler formu doldurduktan sonra zarfı yapıştırmaları istenmiş ve formlar araştırmacı tarafından geri toplanmıştır. Çeşitli nedenler ile ulaşılamayan hemşireler (yıllık izin, rapor v.b.) için farklı tarihlerde tekrarlı ziyaretler yapılmıştır.

\section{Verilerin Değerlendirilmesi}

Standartların uygulanma durumunun değerlendirilmesinde işaretlenmemiş, eksik veriler (59 veri) madde ortalamaları ile tamamlanmıştır (28). Veriler SPSS 22.0 istatistik programı kullanılarak tanımlayıcı istatistikler, non-parametrik tek yönlü varyans analizi ve Bonferroni düzeltmeli Mann-Whitney U testi ile değerlendirilmiştir. G Power yazılım programı ile post hoc yapılan güç analizinde, 0.50 etki büyüklüğü, $\% 5$ hata payı ile Mann-Whitney $U$ analizinde üç karşılaştırma grubu için güç 0.960.98 bulunmuştur.

\section{Araştırmanın Etik Yönü}

Bir üniversitenin Girişimsel Olmayan Araştırmalar Etik Kurul'undan 16.09.2019 tarihinde 2019/23-34 nolu karar ile etik kurul onayı alınmıştır. Araştırmanın yürütüldüğü hastanelerin yönetimlerinden ve İzmir İl Sağlık Müdürlüğü’nden yazılı izinler alınmıştır. Araştırmaya katılan hemşirelerden sözlü onam alınmıştır. Makalenin tüm aşamalarında araştırma ve yayın etiğine uyulmuştur.

\section{Bulgular}

\section{SÇO Ana Standartlar ve Alt Standartların Kurumda Uygulanma Durumunun Değerlendirilmesi}

Hemşireler tarafindan SÇO ana standartlar ve alt standartların uygulanma durumlarının değerlendirilmesi Tablo 2'de yer almaktadır. Hemşire İş Yükü ve Etkili Yönetim ve Liderlik ana standartlarına ait alt standartların ortalamalarının 2' nin altında olduğu belirlenmiştir. Uygun Fiziki Koşullar ve Yeterli Araç-Gereç, Ekip İş Birliği, İletişim, Takdir ve Tanınma, Geliştirme ve Kariyer Planlama ile Sosyal Haklar, İş Sağlığı ve Güvenliği ana standartlarına ait alt standartların ortalamalarının ise 2-2.5 arasında değiştiği görülmektedir. "Ödüllendirme sistemleri adil ve objektifttir" maddesi için \% 1.3 "tamamen katılıyorum" yanıt oranı ve 1.55 ortalama ile tüm alt standartlar içerisinde en az uygulandığı düşünülen standart olmuştur. "Kreş, otopark ve ulaşım gibi sosyal haklar sağlanır" maddesi ise 2.59 ortalama ile en çok uygulandığı ifade edilen alt standart olmuştur (Tablo 2). Ana standartların uygulanma durumu incelendiğinde kurumlarda "Etkili Yönetim ve Liderlik" ana standardının 1.76 ortalama ile en az, "Ekip İş Birliği, İletişim, Takdir ve Tanınma" ana standardının ise 2.27 ortalama ile en çok uygulanan ana standart olduğu bulunmuştur. Standartlarının tümünün uygulanma durumu ise 2.07 ortalamaya sahiptir (Tablo 2). 


\section{Maddeler}

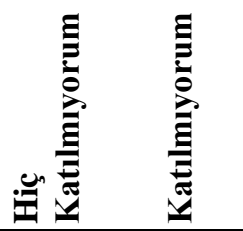

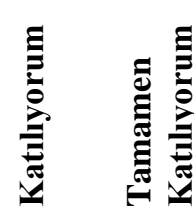

\section{HEMȘÍRE İS YÜKÜ}

1. Her vardiyada hasta-hemşire oranları güvenli bakımı sağlayacak sayı ve niteliktedir.

2. Hemşire işgücü planlaması hemşirelerin mesleki yeterliliklerine göre yapılır.

40.8

3. Her vardiyada görevleri açıça tanımlanan yeterli destek elaman sağlanır.

34.6

41.7

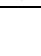

Ana Standart

4. Çalışma süreleri, hasta ve hemşire güvenliği açısından kabul edilebilir sınırlardadır.

\section{GELISTTIRME VE KARIYER PLANLAMA}

6. Kurum içinde gerçekleştirilen hizmet içi eğitim programları hemşirelerin gelişimini destekler.

39.2

22.3

$1.79(0.78)$

7. Her hemşireye ihtiyacına göre eğitim ve geliştirme programlarına katılma fırsatı sağlanır.

$\begin{array}{lllll}13.3 & 32.7 & 48.2 & 5.8 & 2.47(0.80) \\ 28.5 & 42.4 & 27.2 & 1.9 & 2.03(0.80) \\ 12.6 & 32.0 & 47.2 & 8.1 & 2.51(\mathbf{0 . 8 2}) \\ 21.7 & 36.9 & 37.9 & 3.6 & 2.23(0.83) \\ 31.7 & 46.6 & 19.4 & 2.3 & 1.92(0.77) \\ 31.4 & 45.0 & 22.0 & 1.6 & 1.94(0.77) \\ \mathbf{4 8 . 2} & 35.9 & 14.9 & 1.0 & \mathbf{1 . 6 9 ( 0 . 7 6 )} \\ 15.9 & 36.6 & 43.7 & 3.9 & 2.36(0.79)\end{array}$

8. Oryantasyon programı, işe yeni başlayan hemşirelerin uyumunu kolaylaştıracak şekilde uygulanır.

9. Araştırma ve yenilikçi projeler desteklenir.

10. Hemşireler için kariyer planlama firsatları sağlanır.

11. Hemşirelerin mesleki örgütlenmelere katılımı ve faaliyet yürütmeleri desteklenir.

12. Atama ve yükseltmeler liyakate göre yapılır.

13. Eğitim programları kanıta dayalı bakım uygulamalarına temellendirilir.

\section{SOSYAL HAKLAR, ISS SAĞLIĞI VE GÜVENLİĞİ}

14. Meslek hastalıkları ve iş kazaları için gerekli önlemler alınır.

15.Sağlık kontrolleri düzenli olarak yapılır.

16. İș yerinde her türlü şiddete karşı sıfır tolerans politikası uygulanır.

17. Biyolojik, fiziksel ve kimyasal zararlardan korunmak için gerekli önlemler alınır (enfekte atıklar, radyasyon, 33.7 gürültü, ilaç).

18. Riskli alanlara yönelik yasal mevzuata uygun önlemler alınır (radyasyon izini, uygun koruyucu ekipman kullanımı, dozimetre vb.).

19. Çalışanların sağlık hizmetlerine ulaşmaları kolaylaştırılır.

20. Kreș, otopark ve ulașım gibi sosyal haklar sağlanır.

21. Hemsirelerin eğitim düzeyi, iş yükü, risk faktörleri ve vardiya sistemi göz önüne alınarak aletli bir ücret 13.6

21. Hemşirelerin eğitim düzeyi, iş yükü, risk faktörleri ve vardiya sistemi göz önüne alınarak adaletli bir ücret 53.7

$\begin{array}{llll}38.2 & 39.2 & 4.2 & 2.29(0.81) \\ 24.3 & 55.0 & 6.1 & 2.53(0.82) \\ 39.2 & 24.6 & 2.6 & 1.96(0.83) \\ 9.1 & 42.1 & 6.8 & 2.34(0.90) \\ & & & \\ 25.6 & 51.1 & 7.8 & 2.51(0.85) \\ & & & \\ 35.0 & 34.3 & 4.5 & 2.17(0.87) \\ 22.7 & 55.3 & 8.4 & \mathbf{2 . 5 9 ( 0 . 8 3 )} \\ 33.3 & 12.0 & 1.0 & \mathbf{1 . 6 0 ( 0 . 7 3 )}\end{array}$

\section{UYGUN FİİKİ KOŞULLAR VE YETERLİ ARAÇ-GEREÇ}

22. Çalışma ortamı, çalışanların ruhsal ve fiziksel sağlığını koruyacak şekilde düzenlenir.

23. Çalıș1lan birimlere yeterli miktarda sarf malzeme ve araç gereç temin edilir.

1.0
3.6
2.6

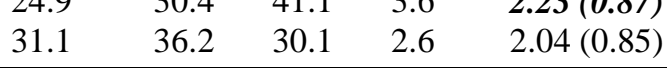




\section{EKİP İS BİRLİĞí, İLETIŞiM, TAKDİR VE TANINMA}

25. Süreçler hemşirelerin sağlık ekibi üyeleriyle iş birliğini destekleyicidir.

18.1

. Hemsireler arasinda meslektas dayanıșması güclendirilir.

27. Ekip üyeleri arasında açık ve etkili iletișim olması desteklenir.

28. Ekip üyeleri arasındaki çatışma nedenlerinin ortadan kaldırılmasına yönelik düzenlemeler vardır.

29. Çalışma ortamında, karşılıklı güven, saygı ve iș birliği vardır.

30. Ekip üyeleri, hemşireliğin bakıma katkısının öneminin farkındadır.

\section{ETKILI YÖNETIM VE LIDERLİK}

31. Hemșirelerin her düzeyde kararlara katılımı sağlanır.

32. Hemşirelerin yönetime güven duyduğu ve geribildirimlerinin değerlendirildiği demokratik bir yönetim

anlayısı benimsenir.

33. Hemşireleri işe alma ve işte tutmada yenilikçi politikalar uygulanır.

34. Ödüllendirme sistemleri adil ve objektiftir.

35. Hemşirelerin çalışmaları üzerinde kontrol sahibi olmaları için özerklikleri desteklenir.

GENEL TOPLAM

*Tabloda her bir maddenin ve her bir ana standardın aldığı en düşük ve en yüksek değerler italik ve bold olarak gösterilmiştir.

$\begin{array}{llll}40.8 & 38.8 & 2.3 & 2.25(0.77)\end{array}$

$21.4 \quad 43.0-32.0 \quad 3.6-2.18(0.80)$

$\begin{array}{lllll}15.9 & 36.9 & 43.4 & 3.9 & 2.35(0.79)\end{array}$

$\begin{array}{lllll}24.6 & 43.7 & 29.1 & 2.6 & 2.10(0.80)\end{array}$

$\begin{array}{lllll}15.9 & 33.3 & 46.0 & 4.9 & \mathbf{2 . 4 0}(\mathbf{0 . 8 1})\end{array}$

$\begin{array}{lllll}22.3 & 27.2 & 44.0 & 6.5 & 2.35(0.90)\end{array}$

$\begin{array}{lllll}27.5 & 50.5 & 21.0 & \mathbf{1 . 0} & \mathbf{1 . 9 5}(\mathbf{0 . 7 2})\end{array}$

43.7

40.1

$15.2 \quad 1.0 \quad 1.73(0.75)$

$\begin{array}{lllll}37.9 & 46.6 & 14.9 & 0.6 & 1.78(0.71)\end{array}$

$\begin{array}{lllll}56.0 & 34.3 & 8.4 & 1.3 & 1.55(0.70)\end{array}$

$\begin{array}{lllll}41.1 & 40.1 & 17.5 & 1.3 & 1.79(0.77)\end{array}$
$2.27(0.63)$

$1.76(0.60)$ 
SÇO Ana Standartlarının Önem Düzeyinin Değerlendirilmesi

Hemşirelerin SÇO ana standartlarının önemlilik düzeylerine ilişkin değerlendirmeler Tablo 3 'te verilmiştir.

Tablo 3. SÇO Ana Standartlarının Önemlilik Derecesinin Stralaması

$$
\text { Önemlilik Derecesi (\%) (n = 309) }
$$

\begin{tabular}{|c|c|c|c|c|c|c|c|c|c|}
\hline ANA STANDART & 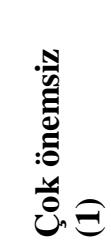 & 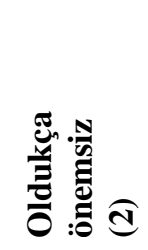 & مَ & 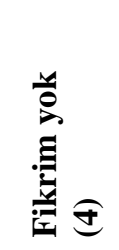 & 国 & 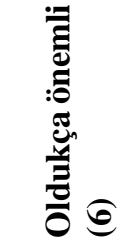 & 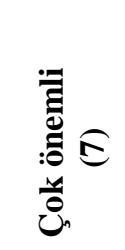 & है & Ort \pm ss \\
\hline Hemşire İş Yükü & 1.0 & 1.6 & 1.3 & 0.6 & 4.5 & 10.7 & 80.3 & 100 & $6.59(1.07)$ \\
\hline Geliştirme ve Kariyer Planlama & 1.0 & 1.9 & 3.6 & 2.6 & 21.7 & 30.4 & 38.8 & 100 & $5.89(1.25)$ \\
\hline $\begin{array}{l}\text { Sosyal Haklar, İş Sağlığı ve } \\
\text { Güvenliği }\end{array}$ & 0.3 & 1.0 & 1.9 & 1.6 & 7.1 & 18.1 & 69.9 & 100 & $6.48(1.01)$ \\
\hline $\begin{array}{l}\text { Uygun Fiziki Koşullar ve Yeterli } \\
\text { Araç-Gereç }\end{array}$ & 0.6 & - & 1.6 & 1.3 & 10.7 & 16.2 & 69.6 & 100 & $6.48(0.97)$ \\
\hline $\begin{array}{l}\text { Ekip İş Birliği, İletişim, Takdir } \\
\text { ve Tanınma }\end{array}$ & 0.3 & 0.6 & 1.9 & 1.6 & 9.1 & 22.3 & 64.1 & 100 & $6.42(0.99)$ \\
\hline tl & 1.0 & & 2 & 2.6 & 13.3 & 0.7 & 59.5 & 100 & $6.28(1.12)$ \\
\hline
\end{tabular}

*Tabloda her bir ana standardın aldığı en düşük ve en yüksek ortalama italik ve bold olarak gösterilmiştir.

Hemşireler tarafından ana standartlar arasında en önemli olarak görülen 6.59 ortalama ile "Hemşire İş Yükü”, en düşük öneme sahip olan ise 5.89 ortalama ile "Geliştirme ve Kariyer Planlama” olarak bulunmuştur (Tablo 3).

SÇO Ana Standartlarının Öncelik Stralamasının Değerlendirilmesi

SÇO ana standartlarının öncelik sıralaması Tablo 4'te verilmiştir.

Tablo 4. SÇO Ana Standartlarının Öncelik Stralaması

Öncelik Sıralaması $(\%)(n=293)$

\begin{tabular}{|c|c|c|c|c|c|c|c|}
\hline ANA STANDART & 1 & 2 & 3 & 4 & 5 & 6 & Toplam \\
\hline Hemşire İş Yükü & 70.3 & 12.6 & 6.1 & 4.1 & 2.4 & 4.4 & 100 \\
\hline Geliştirme ve Kariyer Planlama & 1.4 & 11.9 & 8.2 & 11.6 & 23.9 & 43 & 100 \\
\hline Sosyal Haklar, İş Sağlığı ve Güvenliği & 13.0 & 28.7 & 23.5 & 17.4 & 11.3 & 6.1 & 100 \\
\hline $\begin{array}{l}\text { Uygun Fiziki Koşullar ve Yeterli } \\
\text { Araç-Gereç }\end{array}$ & 2.0 & 24.6 & 31.1 & 24.6 & 10.6 & 7.2 & 100 \\
\hline $\begin{array}{l}\text { Ekip İş Birliği, İletişim, Takdir ve } \\
\text { Tanınma }\end{array}$ & 6.8 & 15.0 & 21.8 & 27.3 & 24.6 & 4.4 & 100 \\
\hline Etkili Yönetim ve Liderlik & 6.5 & 7.2 & 9.6 & 14.7 & 27.3 & 34.8 & 100 \\
\hline
\end{tabular}

*Tabloda "1: çok öncelikli ... 6: az öncelikli" olacak şekilde yapılan sıralamaların yüzdesi verilmiştir.

**Tabloda her bir ana standardın aldığı en yüksek yüzde kalın ve italik yazılmıştır.

Çalışmaya katılan hemşireler, çalıştıkları kurumlarda sağlıklı çalışma ortamı ana standartlarını öncelik sıralamasını "Hemşire İş Yükü” ilk sırada olmak üzere "Sosyal Haklar, İş Sağlı̆̆ı ve Güvenliği”,, "Uygun Fiziki Koşullar ve Yeterli Araç-Gereç”, "Ekip İş Birliği, İletişim, Takdir ve Tanınma", "Etkili Yönetim ve Liderlik", "Geliştirme ve Kariyer Planlama” olarak belirtmişlerdir (Tablo 4).

SÇO Standartlarının Uygulanma Durumunun Cerrahi, Dahili ve Yoğun Bakım Birimlerine Göre Karşılaştırılması SÇO standartlarının cerrahi, dahili ve yoğun bakım birimlerinde uygulanma durumları arasında fark olup olmadığının incelenmesi için ana standartlar ve madde toplamı esas alınmıştır. Tanımlayıcı veriler ve Kruskal Wallis Testi sonuçları Tablo 5 'te sunulmuştur. 
Tablo 5. Cerrahi, Dahili ve Yoğun Bakım Birimlerine Ait Tanımlayıcı Veriler ve Kruskal Wallis Test Sonuçları

\section{DEĞERLER}

$\begin{array}{lllllllll}\text { ANA STANDART } & \text { Birimler } & \mathrm{n} & \text { Min } & \text { Maks } & \begin{array}{l}\text { Ana Standart } \\ \text { Ort } \pm \text { ss }\end{array} & \text { Ort } & X^{2} & \text { Df }\end{array}$

\section{KRUSKAL WALLIS}

\begin{tabular}{|c|c|c|c|c|c|c|c|c|c|}
\hline \multirow{3}{*}{$\begin{array}{l}\text { Hemşire İş Yükü } \\
\text { (5 madde) }\end{array}$} & Cerrahi & 100 & 1.0 & 3.20 & $1.85(0.60)$ & 160.48 & \multirow{3}{*}{.562} & \multirow{3}{*}{2} & \multirow{3}{*}{.755} \\
\hline & Dahili & 116 & 1.0 & 4.0 & 1.78 (0.59) & 152.41 & & & \\
\hline & Yoğun B. & 93 & 1.0 & 3.60 & $1.78(0.56)$ & 152.34 & & & \\
\hline \multirow{3}{*}{$\begin{array}{l}\text { Geliştirme ve } \\
\text { Kariyer Planlama } \\
\text { (8 madde) }\end{array}$} & Cerrahi & 100 & 1.0 & 3.50 & $2.18(0.56)$ & 160.04 & \multirow{3}{*}{.508} & \multirow{3}{*}{2} & \multirow{3}{*}{.776} \\
\hline & Dahili & 116 & 1.0 & 3.38 & $2.13(0.58)$ & 153.63 & & & \\
\hline & Yoğun B. & 93 & 1.0 & 3.38 & $2.12(0.55)$ & 151.30 & & & \\
\hline \multirow{3}{*}{$\begin{array}{l}\text { Sosyal Haklar, İş } \\
\text { Sağlığı ve Güvenliği } \\
\text { (8 madde) }\end{array}$} & Cerrahi & 100 & 1.0 & 3.75 & $2.24(0.55)$ & 153.90 & \multirow{3}{*}{6.071} & \multirow{3}{*}{2} & \multirow{3}{*}{.048} \\
\hline & Dahili & 116 & 1.0 & 3.36 & $2.32(0.62)$ & 169.10 & & & \\
\hline & Yoğun B. & 93 & 1.0 & 4.0 & $2.17(0.53)$ & 138.59 & & & \\
\hline \multirow{3}{*}{$\begin{array}{lr}\text { Uygun } & \text { Fiziki } \\
\text { Koşullar ve } & \text { Yeterli } \\
\text { Araç-Gereç } & \\
\text { ( } 3 \text { madde) }\end{array}$} & Cerrahi & 100 & 1.0 & 3.33 & $2.05(0.63)$ & 162.98 & \multirow{3}{*}{12.570} & \multirow{3}{*}{2} & \multirow{3}{*}{.002} \\
\hline & Dahili & 116 & 1.0 & 4.0 & $2.11(0.71)$ & 169.63 & & & \\
\hline & Yoğun B. & 93 & 1.0 & 4.0 & $1.80(0.68)$ & 128.17 & & & \\
\hline \multirow{3}{*}{$\begin{array}{l}\text { Ekip İş Birliği, } \\
\text { İletişim, Takdir ve } \\
\text { Tanınma } \\
\text { ( } 6 \text { madde) }\end{array}$} & Cerrahi & 100 & 1.0 & 4.0 & $2.28(0.66)$ & 156.08 & \multirow{3}{*}{2.637} & \multirow{3}{*}{2} & \multirow{3}{*}{.268} \\
\hline & Dahili & 116 & 1.0 & 3.83 & $2.32(0.66)$ & 163.40 & & & \\
\hline & Yoğun B. & 93 & 1.0 & 3.50 & $2.20(0.56)$ & 143.37 & & & \\
\hline \multirow{3}{*}{$\begin{array}{l}\text { Etkili Yönetim ve } \\
\text { Liderlik } \\
\text { (5 madde) }\end{array}$} & Cerrahi & 100 & 1.0 & 4.0 & $1.78(0.65)$ & 154.74 & \multirow{3}{*}{2.356} & \multirow{3}{*}{2} & \multirow{3}{*}{.308} \\
\hline & Dahili & 116 & 1.0 & 3.40 & $1.82(0.62)$ & 163.56 & & & \\
\hline & Yoğun B. & 93 & 1.0 & 3.50 & $1.68(0.50)$ & 144.61 & & & \\
\hline \multirow{3}{*}{$\begin{array}{l}\text { Genel Toplam } \\
\text { (35 madde) }\end{array}$} & Cerrahi & 100 & 1.0 & 3.20 & $2.09(0.50)$ & 157.67 & \multirow{3}{*}{3.040} & \multirow{3}{*}{2} & \multirow{3}{*}{.219} \\
\hline & Dahili & 116 & 1.0 & 3.29 & $2.11(0.52)$ & 163.16 & & & \\
\hline & Yoğun B. & 93 & 1.0 & 3.29 & $2.0(0.45)$ & 141.96 & & & \\
\hline
\end{tabular}

$* \mathrm{p}<.05$ olduğu değerler kalın ve italik yazılmıştır.

**Tabloda her bir standardın ve genel toplamın aldığı en yüksek ortalama değerleri kalın yazılmıştır.

SÇO ana standartlarının uygulanma durumu incelendiğinde "Sosyal Haklar, İş Sağlığı ve Güvenliği”, "Uygun Fiziki Koşullar ve Yeterli Araç-Gereç”, "Ekip İş Birliği, İletişim, Takdir ve Tanınma”, "Etkili Yönetim ve Liderlik” ile genel toplamda 
en yüksek puanın dahili birimlerinde olduğu görülmektedir. "Hemşire İş Yükü” ile "Geliştirme ve Kariyer Planlama" ana standartlarında ise cerrahi birimler en yüksek puana sahiptir (Tablo 5). SÇO ana standartlarından "Uygun Fiziki Koşullar ve Yeterli Araç-Gereç" ana standardının uygulanma durumu için birimler arasında istatistiksel olarak anlamlı bir farklılık bulunmuştur $(p<.01)$. Diğer ana standartlar ve tüm standart maddeleri için ise uygulanma durumları arasında anlamlı bir farklılık yoktur ( $p=.755, p=.776, p=.048, p=.268, p=.308, p=.219$; Tablo 5).

Uygun Fiziki Koşullar ve Yeterli Araç-Gereç ana standardındaki farklılığın hangi birimden kaynaklandığına ilişkin ileri analiz sonuçlarına Tablo 6'da yer verilmiştir.

Tablo 6. Uygun Fiziki Koşullar ve Yeterli Araç-Gereç Ana Standardının Birimlere Göre Uygulanma Durumu Farklılığının İncelenmesi

\begin{tabular}{|c|c|c|c|c|}
\hline \multirow{2}{*}{ ANA STANDART } & \multicolumn{4}{|c|}{ Mann-Whitney U Testi } \\
\hline & Birimler & $\mathbf{n}$ & Ort & $\mathbf{p}$ \\
\hline \multirow{6}{*}{$\begin{array}{l}\text { Uygun Fiziki Koşullar ve Yeterli } \\
\text { Araç-Gereç }\end{array}$} & Cerrahi & 100 & 105.49 & \multirow{2}{*}{-.506} \\
\hline & Dahili & 116 & 111.09 & \\
\hline & Cerrahi & 100 & 107.99 & \multirow{2}{*}{-.004} \\
\hline & Yoğun B. & 93 & 85.18 & \\
\hline & Dahili & 116 & 117.03 & \multirow{2}{*}{-.001} \\
\hline & Yoğun B. & 93 & 89.99 & \\
\hline
\end{tabular}

*p<.016 olduğu değerler kalın ve italik yazılmıştır.

Yapılan ileri analiz sonucunda, "Uygun Fiziki Koşullar ve Yeterli Araç-Gereç" ana standardındaki farklılığın yoğun bakım birimlerinde bu ana standardın daha az uygulanmasından kaynaklandığı anlaşılmıştır (Tablo 6).

\section{Tartışma}

\section{SÇO Standartlarının Kurumda Uygulanma Durumları}

Sağlıklı çalışma ortamı alt standartlarının yaklaşık yarısının ortalamasının 2'nin altında kaldığı, en çok uygulanan alt standardın ortalamasının bile ancak 2.5'i geçebildiği, alt standartların ve buna paralel olarak ana standartların genel olarak kurumlarda düşük ya da orta düzeyde uygulandığı görülmüştür. AACN'nin 2005 yılında belirlediği standartların ABD hastanelerinde uygulanma durumlarının incelendiği çalışmalarda "Yeterli Personel” standardı maddeleri hariç diğer tüm standart maddelerinin ortalamalarının 2.5'i geçtiği; standartların orta düzeyin biraz üzerinde uygulandığı görülmektedir (AACN, 2005). Yeterli Personel standardının alt maddeleri ise yıllara göre 2 ile 2.5 arasında değişmektedir. Çalışmamızda ise Yeterli Personel standardı ile benzer alanı içeren Hemşire İş Yükü ana standardına bağlı alt standartların ortalamaları 2'nin altında kalarak diğer ana standartlar içerisinde en düşük düzeyde karşılanan ana standartlardan birisi olmuştur. Bu benzerlik, güvenli ve kaliteli bakımın sürekliliği için nitelikli ve yeterli personelin sağlanmasının ülkemizde olduğu gibi hemşirelik mesleğinin daha iyi standartlarda yürütüldüğü ABD'de de sorun olduğunu göstermektedir. Araştırmamızda en yüksek ortalamaya sahip olmasına rağmen Ekip İş Birliği, İletişim, Takdir ve Tanınma alt standartlarının AACN'nin Nitelikli İletişim, İş Birliği ve Tanınma maddeleri ile karşılaştırıldığında yine daha düşük düzeyde uygulandığı anlaşılmıştır (19-22). AACN'nin çalışma ortamı standartlarından Liderlik ana standardının ortalamasının 2.5'in üzerinde olduğu, bizim çalışmamızda ise Etkili Yönetim ve Liderlik standardının tüm madde ortalamalarının 2'in altında kaldığı görülmüştür. Dünya Sağlık Örgütü (DSÖ)'nün 2020 yılında yayınladığ1 raporda, liderlik eğitim programı uygulayan ülkelerin hemşirelerin çalışma koşullarının düzenlenmesinde daha iyi sonuçlar elde ettiğini; hemşirelere yönelik liderlik eğitim programlarının çalışma ortamının düzenlenmesi ile güçlü şekilde ilişkili olduğu belirtmiştir (29). Seren İntepeler ve Barış'ın (2018) derleme çalışmasında da hemşire liderlerin benimsediği ve geliştirdiği liderlik becerilerinin sağlıklı çalışma ortamlarının oluşturulmasında öneminin büyük olduğu vurgulanmıştır (30). Ülkemizde yönetici hemşirelerle yapılan çalışmalar, yönetici hemşirelerin büyük bir kısmının yöneticilik eğitimi almadıklarını göstermektedir (31,32,33). Bununla birlikte çoğunlukla yönetici hemşireler liyakat ve yönetici eğitimi dikkate alınmadan seçilmektedir. Çalışmamızda "Atama ve yükseltmeler liyakate göre yapılır” alt standardının Kariyer Planlama ve Geliştirme ana standardı içinde en düşük ortalamaya sahip olması da bu durumu destekler niteliktedir.

Çalışmamızda Etkili Yönetim ve Liderlik ana standardı en az uygulandığı düşünülen ana standart olurken Ekip İş Birliği, İletişim, Takdir ve Tanınma ana standardının en çok uygulandığı belirtilen ana standart olmuştur. Meslektaş dayanışması, çalışma ortamını çekici kılan ve iş motivasyonunu arttıran önemli bir unsur olması nedeniyle önemlidir (34,35). Ülkemizde yapılan çalışmalarda, hemşirelerin meslektaşlarına karşı dayanışma gösterme tutumları (36-39) ve çalışma arkadaşları tarafindan gördükleri destek algılarının yüksek olduğu belirlenmiştir (40). Etkili Yönetim ve Liderlik ana standardının düşük düzeyde sağlandığı çalışma ortamında Ekip İş Birliği, İletişim, Takdir ve Tanınma ana standardının en çok uygulanan ana standart olmasının hemşireler arasındaki meslektaş ilişkileri ve çalışma arkadaşlarından algıladıkları destek nedeniyle olabileceğini düşündürmektedir.

Türkiye Sağlık Enstitüleri Başkanlığı Sağlık Hizmetleri Kalite ve Akreditasyon Enstitüsü; Sağlıkta Kalite Standartları (SKS) Hastane 6 Versiyonunda "Sağlıklı Çalışma Yaşamı" bölümünde tüm sağlık çalışanlarını kapsayacak şekilde çalışma 
ortamlarının iyileştirilmesi için standartlar tanımlanmıştır. Standartlar incelendiğinde hemşirelere ya da diğer meslek üyelerine özgü olmadığı anlaşılmaktadır. Aynı zamanda bu bölümün çekirdek standartları çalışmamızdaki Sosyal Haklar, İş Sağlığı ve Güvenliği ana standardını kapsayacak şekilde sadece bir boyuta odaklanmaktadır (41). Nitekim çalışmamızda Sosyal Haklar, İş Sağlığı ve Güvenliği ana standardı en çok uygulanan ikinci ana standart olarak çıkmasının, hastanelerde SKS çekirdek standartlarının uygulanmasıyla mümkün olduğunu düşündürtmektedir. Bu sonuç Hemşireler İçin SÇO Standartları'nın, SKS' ye dahil edilerek hemşirelere sağlıklı ve güvenli çalışma ortamının oluşturulmasını ve ulusal bazda değerlendirilip, takip edilmesini kolaylaştırabileceğini göstermektedir.

\section{SÇO Ana Standartlarının Önemlilik Düzeyi ve Öncelik Sıralaması}

Çalışmaya katılan hemşirelere göre, en az uygulanan ikinci ana standart olarak Hemşire İş Yükü olduğu görülmekle birlikte hem en önemli hem de kurumda hayata geçirilmesi en öncelikli ana standart olmuştur. Türkiye İstatistik Kurumu'nun (TÜİK) 2018 y1lı verilerine göre Türkiye'de 190.499 hemşire çalışmakta olup, bir hemşireye ortalama 430 kişi düşmektedir (42). Ülkemizde yıllara oranla çalışan hemşire sayısı artmasına ve bir hemşire başına düşen kişi sayısı azalmasına karşın henüz istenilen düzeye ulaşılamamıştır. Ekonomik İş Birliği ve Kalkınma Teşkilatı (Organisation for Economic Cooperation and Development/OECD), aralarında Türkiye'nin de bulunduğu 36 ülkede, 2000 yılından 2017 yılına kadar 1000 kişiye düşen hemşire sayısının arttığını, Türkiye'de 1000 kişiye düşen hemşire sayısının 2.1 olduğunu ve üye ülkeler arasında Türkiye'nin son sıralarda olduğunu belirtmektedir (43). Ulusal ve uluslararası veriler dikkate alındığında çalışmamızın hemşire iş yükü ana standardına yönelik sonuçlarının beklentilerle uyumlu olduğu söylenebilir.

Araştırmamızda genel olarak ana standartların önem düzeylerinin ve öncelik sıralamalarının birbiriyle uyumlu olduğu görülmektedir. Burada dikkat çekici olan nokta ise Geliştirme ve Kariyer Planlama ana standardını önemliliğinin ve önceliğinin son sırada olmasıdır. Ülkemizde geliştirme ve kariyer olanaklarıyla ilgili görüşlerin incelendiği çalışmalarda; hemşireler kurumlarında kariyer planlama ve geliştirme uygulamalarının olmadığını, var olan kariyer planlama ve geliştirme uygulamalarının ise yetersiz olduğunu, kurumlarındaki açık pozisyonlar için bilgilendirme yapılmadığını, kariyer anlamında mevcut pozisyonlarından memnun olmadıkları görülmektedir (44,45). Sevinç ve Sabuncu'nun (2018) çalışmasında hemşirelerin yarısına yakınının yönlendirme ve kariyer planlama yapılmasını istedikleri, \%60'a yakını ise eğitim programlarının düzenlenmesini istedikleri bulunmuştur. Yine aynı çalışmada hemşirelerin \%56.1'i geliştirme ve kariyer planlamanın hemşirelik mesleğinin geliştirmesinde etkin bir yöntem olacağını belirtmiş, geliştirme ve kariyer planlamanın etkin sürdürülebilmesi için çalışma ortamlarında sürekli eğitim programlarının hazırlanması, hemşire sayısının arttırılması, işe alma ve yerleştirmede eğitim ve uzmanlıkların dikkate alınması gerektiğini ifade etmişlerdir (44). Yöneticilerin yönetsel yeterlilik düzeylerinin incelendiği bir çalışmada ise yönetici hemşirelerin kariyer planlama ile ilgili alanda kendilerini daha az yeterli gördükleri bulunmuştur (32). Sağlık Bakanlığı'nın bütçe yönetmeliğinde hemşirelere yönelik kariyer planlama ve geliştirme için bütçenin ayrılmamış olması dikkate alındığında (46), geliştirme ve kariyer planlama alanlarında istenilen düzeye ulaşılmamış olmasının hem nedeni hem de göstergesi olarak düşünülebilir. Araştırma sonuçları ve bu çalışmanın bulguları, hemşirelik eğitiminde ve sonrasında çalışma ortamlarında, geliştirme ve kariyer planlama ile ilgili konulara daha fazla odaklanılması gerektiğini, yönetici hemşirelerin kariyer planlama konusunda yetkinlik kazanmasının önemini göstermektedir.

\section{SÇO Standartlarının Cerrahi, Dahili ve Yoğun Bakım Birimlerinde Uygulanma Durumu Farklılıkları}

Çalışmamız cerrahi, dahili ve yoğun bakım birimlerinde SÇO standartlarının tümünün uygulanma durumu arasında herhangi bir farkın olmadığını göstermiştir. Ancak her bir ana standart ayrı ayrı incelendiğinde sadece Uygun Fiziki Koşullar ve Yeterli Araç Gereçler ana standardının yoğun bakım birimlerinde cerrahi ve dahili birimlere oranla daha az uygulandığını ortaya koymuştur. Yoğun bakımlarda hemşirelerin çalışma ortamlarını inceleyen Altınöz ve Demir (2017), hemşirelerin yaşadıkları sorunlar içerisinde malzeme yetersizliğinin ikinci sırada olduğunu belirlemişlerdir (47). Bir başka çalışmada ise cerrahi, dahili ve diğer birimlere oranla yoğun bakım birimlerindeki çalışma ortamının hemşireler tarafından daha kötü algılandığını, insan gücü ve kaynak yeterliliği dahil çalışma ortamının diğer özelliklerinin de daha düşük düzeyde sağlandığı sonucuna varılmıştır (1). Yoğun bakım birimlerinde insan gücü ve kaynak yeterliliğinin en düşük düzeyde sağlandığı yapılan başka çalışmalarla da gösterilmiştir $(48,49,50)$. Ülkemizde yapılan kalitatif bir çalışmada da yoğun bakım birimlerinde çalışan hemşirelerin fiziki koşulların yetersiz olduğunu ve araç gereç eksikliği yaşadıkları belirlenmiştir (25). Bu sonuçlar yoğun bakım birimlerinde bulgularımızla uyumlu bir şekilde yeterli araç gerecin sağlanmasında eksiklik olduğunu ve fiziki koşulların uygun olmadığını göstermektedir. Ülkemizde yoğun bakımlar için yönetmeliklerle belirlenmiş özel fiziki standartlar ve çalışacak hemşire sayısının (örneğin üçüncü derece yoğun bakımda her 3 yatak için 1 hemşire) belirlenmiş olması (51), standartların yoğun bakım birimlerinde daha iyi düzeyde uygulanıyor olacağı beklentisi oluşturmaktadır. Çalışmamız ve diğer araştırmalar, ülkemizde yönetmeliklerle belirlenmiş standartların yoğun bakım hemşirelerinin çalışma ortamındaki gereksinimlerini karşılayamadığını; fiziki şartlar, yeterli araç gereç ve insan gücü bakımından eksikliğin devam ettiğini göstermektedir.

\section{Kisitlılıklar}

Sağlık Bakanlı̆̆g’na bağlı eğitim araştırma hastaneleri örneklemini kapsaması ve kesitsel bir çalışma olması araştırmanın sınırlılıkları olarak değerlendirilmiştir.

\section{Sonuçların Uygulamada Kullanımı}

Araştırma sonuçlarının, yönetici hemşireleri, hükümet ve politika yapıcıları hemşirelere sağlıklı çalışma ortamları oluşturulması için harekete geçirmesi ve yapılacak iyileştirmeler için temel oluşturacağı öngörülmektedir. Standartların ülke çapında uygulanması, kısa vadede hızlı sonuçlara ulaşmayı sağlayabileceği gerçeği göz önünde bulundurularak, SÇO standartlarının Sağlıkta Kalite Standartlarına dahil edilmesi bu yolda önemli bir adım olacaktır. Kurumlarda ise yönetici hemşireler belirli aralıklarla SÇO standartları açısından mevcut durum ve girişimlerinin sonuçlarını sistematik biçimde izlemeli ve düşük olan 
alanlarda nedenler araştırılıp uygun stratejiler belirlenmelidir.

\section{Bilgilendirme}

Yazarların çalışmaya katkıları: Fikir ve kavram: DY, HAY; tasarım: DY, HAY; denetleme ve danışmanlık: HAY; veri toplama ve işleme: DY; analiz ve yorum: DY, HAY; kaynak taraması: DY; makalenin yazımı: DY, HAY; eleştirel değerlendirme: HAY. Araştırma ile ilgili herhangi bir projeden ya da firmadan destek alınmamıştır. Araştırmanın bütçesi araştırmacılar tarafından karşılanmıştır. Yazarlar arasında herhangi bir çıkar çatışması yoktur. Ayrıca sorumlu olduğumuz araştırmada herhangi bir firma ile çıkar iliş̧isi bulunmamaktadır. Araştırmanın yapılabilmesi için bir üniversitenin Girişimsel Olmayan Araştırmalar Etik Kurulu’ndan 16.09.2019 tarihinde 2019/23-34 nolu karar ile etik kurul onayı alınmıştır. 


\section{Kaynaklar}

1. Aslan M, Gökdemir S. Hastanede çalışan hemşirelerin çalışma ortamı algısı: Trakya örneği. Yükseköğretim ve Bilim Dergisi 2019;9(3):614-621.

2. Kaddourah B, Abu-Shaheen A K, Al-Tannir M. Quality of nursing work life and turnover intention among nurses of tertiary care hospitals in Riyadh: a cross-sectional survey. BMC Nursing 2018;17(43).

3. Topçu İ, Türkmen E, Badır A, Göktepe N, Miral M, Albayrak S ve ark. Relationship between nurses' practice environments and nursing outcomes in Turkey. Int Nurs Rev 2016;63(2):242-249.

4. Lee Y W, Dai Y T, Park C G, Mccreary L L. Predicting quality of work life on nurses' intention to leave. J Nurs Scholarsh 2013;45(2):160-168.

5. Nursing Solutions (NS). 2020 NSI National health care retention \& RN staffing report, 2020, URL: https://www.nsinursingsolutions.com/Documents/Library/NSI_National_Health_Care_Retention_Report.pdf. 12 Kasim 2020

6. Koçaşlı S, Aktaş D, Avcı K. Bir eğitim araştırma hastanesinde hemşirelerin kurumdan ayrılmayı isteme nedenlerinin incelenmesi. HEAD 2017;14(2):127-130.

7. Nelson-Brantley H V, Park S H, Bergquist-Beringer S. Characteristics of the nursing practice environment associated with lower unit-level RN turnover. J Nurs Adm 2018;48(1):31-37.

8. Laschinger H K S, Fida R. Linking nurses' perceptions of patient care quality to job satisfaction: the role of authentic leadership and empowering professional practice environments. J Nurs Adm 2015;45(5):276-83.

9. Wang Y, Zhang L, Tian S, Wu J, Lu J, Wang F ve ark. The relationship between work environment and career success among nurses with a master's or doctoral degree: a national cross-sectional study. Int J Nurs Pract 2019;25(4):e12743.

10. Kol E, İlaslan E, Turkay M. The effectiveness of strategies similar to the magnet model to create positive work environments on nurse satisfaction. Int J Nurs Pract 2017;23:e12557.

11. Numminen O, Ruoppa E, Leino-Kilpi H, Isoaho H, Hupli M, Meretoja R. Practice environment and its association with professional competence and work-related factors: perception of newly graduated nurses. J Nurs Manag 2016;24(1):E1-E11.

12. Bai J. Does job satisfaction mediate the relationship between healthy work environment and care quality?. Nurs Crit Care 2016;21(1):18-27.

13. Stalpers D, De Brouwer B J, Kaljouw M J, Schuurmans M J. Associations between characteristics of the nurse work environment and five nurse-sensitive patient outcomes in hospitals: a systematic review of literature. Int $\mathrm{J}$ Nurs Stud 2015;52(4):817-835.

14. Aiken L H, Sloane D M, Bruyneel L, Van Den Heede K, Griffiths P, Busse R ve ark. Nurse staffing and education and hospital mortality in nine European countries: a retrospective observation study. Lancet 2014;383(9931):1824-1830.

15. Tei-Tominaga M, Sato F. Effect of nurses' work environment on patient satisfaction: a cross-sectional study of four hospitals in Japan. Jpn J Nurs Sci 2016;13(1):105-113.

16. International Council of Nurses (ICN). Positive practice environments: quality work places = quality patient care Information and action tool kit, Geneva, 2007, URL: https://www.caccn.ca/files/ind kit final2007.pdf. 12 Kasim 2020

17. Registered Nurses' Association of Ontario (RNAO). Workplace health, safety and well-being of the nurse. Toronto, Canada, 2008, URL: http://www.mtpinnacle.com/pdfs/RNAO_BPG_Health_Safety.pdf. 12 Kasim 2020

18. American Association of Critical-Care Nurses (AACN). AACN standards for establishing and sustaining healthy work environments: a journey to excellence. Am J Crit Care 2005;14(3):187-197.

19. Ulrich B T, Lavandero R, Hart K A, Woods D, Leggett J, Taylor D. Critical care nurses’ work environments: a baseline status report. Crit Care Nurse 2006;26(5):46-57.

20. Ulrich B T, Lavandero R, Hart K A, Woods D, Leggett J, Friedman D ve ark. Critical care nurses' work environments 2008: a follow-up report. Crit Care Nurse 2009;29(2):93-102.

21. Ulrich B T, Lavandero R, Woods D, Early S. Critical care nurse work environments 2013: a status report. Crit Care Nurse 2014;34(4):64-79.

22. Ulrich B, Barden C, Cassidy L, Varn-Davis N. Critical care nurse work environments 2018: findings and implications. Crit Care Nurse 2019;39(2):67-84.

23. Erdağı S, Özer N. Cerrahi kliniklerde çalışan hemşirelerin çalışma ortamlarının, hasta güvenliği kültürü algılarının ve tükenmişlik durumlarının incelenmesi. Anadolu Hemşirelik ve Sağlık Bilimleri Dergisi 2013;18(2):94-106.

24. Arslan Yürümezoğlu H, Kocaman G. Predictors of nurses' intentions to leave the organisation and the profession in Turkey. J Nurs Manag 2016;24(2):235-243.

25. Samur M, Seren Intepeler S. Nurses' view of their work environment, health and safety: a qualitative study. J Nurs Manag 2019;27(7):1400-1408.

26. Kocaman G, Arslan Yürümezoğlu H, Uncu S, Türkmen E, Göktepe N, Seren İntepeler S. Türkiye'de hemşireler için sağlıklı çalışma ortamı standartlarının geliştirmesi. HEAD 2018;15(1):30-38.

27. Bayat B. Uygulamalı sosyal bilim araştırmalarında ölçme, ölçekler ve "likert" ölçek kurma tekniği. Gazi Üniversitesi İktisadi ve İdari Bilimler Fakültesi Dergisi 2015;16(3):1-24.

28. Şeker Ş E, Eşmekaya E. Eksik verilerin tamamlanması (Imputation). YBS Ansiklopedi 2017;4(3):10-17.

29. World Health Organization (WHO). State of the world's nursing 2020: investing in education, jobs and leadership, Geneva, 2020

URL: https://www.who.int/publications/i/item/9789240003279. 12 Ekim 2020

30. Seren İntepeler Ş, Barış V K. Dönüşümcü ve etkileşimci lider-izleyen ilişkilerinin hemşirelik ve sağlık hizmetlerine etkisi. ACU Sağlık Bil Derg 2018;9(2):97-104. 
31. Alan H, Baykal U. Yönetici hemşirelerin kişilik özellikleri ve etkileyen kişisel ve mesleki özellikler. Psikiyatri Hemşireliği Dergisi 2018;9(2):119-128.

32. Karadaş A, Duran S, Doğu Ö. Servis sorumlu hemşirelerinin yönetsel yeterlik düzeylerinin belirlenmesi: Balıkesir ve Sakarya örnekleri. Mersin Univ Saglık Bilim Derg 2017;10(1):54-64.

33. Ünaldı Baydın N, Topçu İ, Tiryaki Şen H, Ateş N, Erdem B, Yıldırım A. Kamu hastanelerinde çalışan yönetici hemşirelerin liderlik davranışları üzerine bir araştırma. Sağlık ve Hemşirelik Yönetimi Dergisi 2017;4(3):89-97.

34. Ahlstedt C, Lindvall C E, Holmström I K, Athlin Å M. What makes registered nurses remain in work? An ethnographic study. Int J Nurs Stud 2019;89:32-38.

35. Göktepe N, Yalçın B, Türkmen E, Dirican Ü, Aydın M. The relationship between nurses' work-related variables, colleague solidarity and job motivation. J Nurs Manag 2020;28(3):514-521.

36. Uslusoy Çetinkaya E, Gürdoğan Paslı E, Kurt D. Hemşirelerde mesleki benlik saygısı ve meslektaş dayanışması. SDÜ Sağlik Bilimleri Dergisi 2016;7(1):29-35.

37. Uslusoy Çetinkaya E, Gürdoğan Paslı E. Hemşirelerde empatik eğilim meslektaş dayanışmasını etkiliyor mu?. Adnan Menderes Üniversitesi Sağllk Bilimleri Fakültesi Dergisi 2019;3(1):19-29.

38. Kilıç E, Altuntaş S. The effect of collegial solidarity among nurses on the organizational climate. Int Nurs Rev 2019;66:356-365.

39. Dan X, Xu S, Liu J, Hou R, Liu Y, Ma H. Innovative behaviour and career success: Mediating roles of self-efficacy and colleague solidarity of nurses. Int J Nurs Sci 2018; 5(3):275-280.

40. Terzi B, Polat Ş. Hemşirelerin algıladıkları destek düzeyleri ve etkileyen faktörlerin incelenmesi. Adıyaman Üniversitesi Sağlık Bilimleri Dergisi 2020;6(1):59-67.

41. Sağlık Hizmetleri Genel Müdürlüğü. Sağlıkta Kalite Standartları, Hastane (Sürüm 6). 1. Baskı. Ankara: Tam Pozitif Matbaa; 2020.

42. Türkiye İstatistik Kurumu (TUIK). Sağlık İstatistikleri, 2018 URL: http://tuik.gov.tr/PreTablo.do?alt id=1095. 12 Ekim 2020

43. Organisation for Economic Co-operationand Development (OECD). Health at a glance 2019: OECD Indicators, OECD Publishing, Paris, 2019.

URL: https://www.oecd-ilibrary.org/docserver/4dd50c09en.pdf?expires=1595267652\&id=id\&accname=guest\&checksum=7B645C0D69B1E1487CC943895E78CF85. $\quad 12$ Ekim 2020

44. Sevinç E, Sabuncu N. Kariyer planlama ve geliştirme uygulamalarına iliş̧kin bir özel hastanede çalışan hemşirelerin görüşleri. İstanbul Gelişim Üniversitesi Sağllk Bilimleri Dergisi 2018;(6):585-606.

45. Bektemür G, Demiray S, Özdemir Ürkmez D. Hemşirelerin kariyer planlaması: bir eğitim ve araştırma hastanesi örneği. Okmeydanı Tıp Dergisi 2016;32(1):7-13.

46. Sağlık Bakanlığı. Sağ lık bakanlığı ile bağlı kuruluşlarının döner sermaye işletmeleri hakkında yönetmelik. Resmi Gazete, 15 May1s 2017, Say1: 30067. URL: https://khgmbutcemuhasebedb.saglik.gov.tr/Eklenti/23461/0/saglikbakanligi-ile-bagli-kuruluslarinin-doner-sermaye-isletmeleri-hakkinda-yonetmelik-15052017-tarihli-ve-30067-sayilirgpdf.pdf

47. Altınöz Ü, Demir S. Yoğun bakımda çalışan hemşirelerde çalışma ortamı algısı, psikolojik distres ve etkileyen faktörler. Psikiyatri Hemşireliği Dergisi 2017;8(2):95-101.

48. Bitek D E, Akyol A D. Yoğun bakım hemşirelerinin çalışma ortamına iliş̧in algıları ile iş doyumları arasındaki ilişkinin incelenmesi. Yoğun Bakım Hemşireliği Dergisi 2017;21(1):1-6.

49. Azevedo Filho F M, Rodrigues M C S, Cimiotti J P. Nursing practice environment in intensive care units. Acta Paul Enferm 2018;31(2):217-23.

50. Oliveira EM, Barbosa RL, Andolhe R, Eiras FRC, Padilha KG. Nursing practice environment and work satisfaction in critical units. Rev Bras Enferm 2017;70(1):73-80.

51. Sağlık Bakanlığı. Yataklı sağlık tesislerinde yoğun bakım hizmetlerinin uygulama usul ve esasları hakkında tebliğde değişiklik yapılmasına dair tebliğ. Resmi Gazete, 22 Mart 2017, Sayı: $30015 . \quad$ URL: http://www.resmigazete.gov.tr/eskiler/2017/03/20170322-31.htm. 12 Ekim 2020 